\title{
THE IMAGE OF GYPSIES IN THE CONTEMPORARY RUSSIAN SOCIETY
}

\author{
Assoc. Prof. PhD (Philosophy) Ksenya Reznikova ${ }^{1}$ \\ Assoc. Prof. PhD (Philosophy) Natalia Seredkina \\ Assoc. Prof. PhD (Philosophy) Julia Zamaraeva \\ Assoc. Prof. PhD (Philosophy) Anastasiya Kistova \\ Assoc. Prof. PhD (Philosophy) Natalia Pimenova \\ ${ }^{1}$ Siberian Federal University, Russia
}

\begin{abstract}
The Gypsies are one of the most controversial ethnic groups. Periodically the actions of Gypsies (including their individual representatives) cause such violent surges of discontent that can be settled only by law enforcement authorities. For example, in August 2016 in Ukrainian village of Loschinovka there were pogroms of houses inhabited by Gypsy families, in response to the murder of a local girl by a Gypsy; in March 2016, in Tula village of Plekhanovo enforcement authorities were engaged in connection with the illegal tapping into the gas pipeline by the local Gypsies, etc. This paper studies public perception of Gypsies, forcing violent and abrupt reactions of other people to actions of Gypsies; it also investigates the causes of such perception, ways of their formation and possibilities of their change.

The study is based on the discussion in the "Live journal" in August 2016, initiated by a Gypsy, in which young parents took part. The research method is narrative analysis. The contributing opinions to the discussion (more than 400), have been analyzed from the perspective of the image, the Russians have of Gypsies, and the features that are considered most typical.

The following components of the image of Gypsies were analyzed in the study: appearance, places of settlement, types of employment, victims of Gypsies, techniques for resisting Gypsies, attitude to Gypsies, attitude of Gypsies towards Gypsies and nonGypsies, ways to change the attitude towards Gypsies.

The Gypsies are identified by the representatives of other ethnic groups primarily by their appearance, occupation and places of settlement. The victims of illegal actions of Gypsies are mainly women. The techniques to resist Gypsies are ignoring them, using their own methods, search for protection. Gypsies clearly identify people as their own kind and others, which they appear to do on the basis of blood relations. They actively and even aggressively protect people of their own kind; the attitude to others is bad. Gypsies believe constructivism is the means to change the attitude of other people towards them. Representatives of other ethnic groups believe that constructivism can be applied only on the basis of Gypsies' modifying their own behaviour.
\end{abstract}

Keywords: Gypsies, narrative analysis, ethnic group, identity, constructivism. 


\section{INTRODUCTION}

Interethnic relations in modern society are the object of many scientific studies. One of the most controversial issues is the question of the Gypsies' positioning themselves in the society and the society's perception of them. Of great interest to researches are the social reactions, presented in the Internet forums, regarding the Gypsies, one of the most closed communities not only in Europe, but also in Russia [1, 2]. The interest in this ethno-cultural group is largely due to the actions of Gypsies themselves (the pogroms of houses, inhabited by Gypsy families in the Ukrainian village of Loschinovka in August 2016 [3]; illegal tapping into the gas pipelines by the local Gypsies in the Tula village of Plekhanovo in March 2016 [4], etc.), which caused vehement reaction of the society, which was often openly hostile [5, 6]. In many ways such attitude is also caused by the historical memory [7] about the Gypsies, whose main markers are the notions of "Gypsy encampment" and "beggars". The existing conflict situations form the image of Gypsies as marginal [8], often living even today in the situations of racism [9]. On the other hand, currently the level of political activity of Gypsies is quite high, along with the spread of national initiatives, aimed at supporting social solidarity in relation to this ethnic group [10], to the mutual enrichment of cultures in general $[11,12]$. In short, the identity of Gypsies is quite actively constructed on the basis of the intersection of political and expert knowledge of various participants, including politicians, Gypsy activists, international organizations and scholars. For example, A. Tremlett, considers the possibility of introduction of a new concept concerning the studies of the culture of Gypsies - the "Super-diversity", which demonstrates the peculiarities of this group of people in a more positive light, recognizing their difference, linguistic, cultural, socio-economical diversity [13]. Marushiakova E. and Popov V. believe that the specially conducted policy of integration of Gypsies into the society contributes to even greater stigmatization of Gypsies, separating them from the rest of the society [14]. Anyway, being one of the most ambiguously perceived communities (including very negative perceptions), Gypsies remain at the heart of the scientific discussions. In this paper we attempt to study the perception of Gypsies by Russian people, propose possible strategies of formation and change of these perceptions among the population.

\section{MATERIALS AND METHODS}

The study is based on the discussion in the "Live journal" [15] in August 2016, initiated by a Gypsy, in which young parents (mostly women) took part. The topic of the discussion was set as follows: "Lashë tes, Russian sisters! Tell me, are your kids afraid of us, Gypsies, when they see us in the streets? And what do you tell them about us? Thank you. (I'm just curious to know whether all Russians lie to their children that we are all drug traffickers and- what a tale- that we steal children- or not...)". The total number of comments on this topic was 438.

The research method is narrative analysis. The opinions submitted to the discussion have been analyzed from the perspective of the image that Russians have of Gypsies, their perception of the most characteristic features of this ethnic group. They are: appearance, places of settlement, occupations and others. 


\section{RESULTS}

Appearance of Gypsies. Appearance is one of the most important markers of Gypsy ethnic group. Gypsy women have a more distinctive appearance than men. This is due, firstly, to traditional clothing - gypsies wear shawls, long skirts; secondly, the characteristic of a Gypsy woman is a number of untidy children nearby. The participants of the discussion were unable to identify phenotypic features of Gypsies. Therefore, if Gypsies are not dressed in their traditional clothes and are not surrounded by children, they cannot be identified as belonging to this ethnic group.

Places of settlement of Gypsies. Many participants of the discussion noted that at present there are fewer Gypsies, at least, in big cities. In Moscow, Gypsies can be encountered at railway stations; they are rarely seen the city itself. Gypsies live in Tula region, Bryansk, in Ufa, in Ivanovo region, and others. As a rule, Gypsies live in villages, towns or in urban private sector. Sometimes they occupy the whole village or make up a significant part of its population, or live in encampments. Safe areas, in the opinion of the participants of the discussion, are not associated with Gypsies.

Types of occupation of Gypsies. Types of occupation of Gypsies can be divided into two groups. To the first group belong occupations, positively or neutrally evaluated by the society. To the second group belong occupations, which are assessed negatively. According to participants of the discussion, only few Gypsies are engaged into occupations from the first group. Positively or neutrally viewed occupations are art, metalwork, factory production, sports, science. Arts, in which Gypsies are engaged, are theatre, dancing and singing. But opinions of the participants divided in evaluating even this sphere of activity. Some people (and first of the Gypsy man himself) consider Gypsy art to be quite good and even outstanding; while others have a dismissive or extremely negative opinion. The participant who initiated the discussion identifies with Kotljary, that is people working with metal. In addition to the initiator of the discussion, tinsmiths -Gypsies were mentioned only by two participants, one of whom had a negative opinion. Gypsies scientists, sportsmen and factory workers are referred to the in the comments just once.

The participants of the discussion negatively evaluate illegal activities of Gypsies (theft, robbery, drug trafficking, illegal possession of weapons), as well as fortune-telling, begging, etc. Most commentators cite examples of illegal seizure of property, carried out by Gypsies. Gypsies steal not only property, but also children. The opinion of the Gypsy, involved in the discussions about theft is ambiguous. On the one hand, the ability to steal is regarded by him as a distinctive feature of his ethnicity, which he was even proud of (some participants also tend to view the ability to steal as the talent of Gypsies). On the other hand, the same Gypsy says that thieves among the Roma are not common, that is a myth.

A typically female activity among Gypsies is fortune telling ; a Gypsy not only tells fortune, but can also cast spells and charms and actively offers these services. For the rejection of fortune telling or other services Gypsies curse. Gypsy also beg, and, as noted by the participants of the forum, they do it not in the form of pleading alms, but more aggressively; children are actively involved in begging as well. Also Gypsy teenagers beat other teenagers. Overall, for the most part, Gypsies are involved, from the point of view of the participants of the discussion, in bad occupations. Not once it is mentioned that Gypsies litter a lot. 
The victims of Gypsies and techniques of resisting them. As a rule, the victims of Gypsies are women: participants of the debate, as well as their female relatives and friends. Not only individuals can become victims, but also enterprises, in particular associated with the gas industry.

As a measure of the resistance to Gypsies three ways of action are usually named. Firstly, ignore them. This is the simplest method of dealing with Gypsies move to the other side of the street, do not talk, etc. Secondly, the repetition of the techniques of Gypsies: for example, offer to tell them fortune or curse them. Thirdly, search for protection from those who are perceived as stronger ones. As a rule, women being the potential victims of Gypsies, perceive men, including relatives and representatives of law enforcement bodies as stronger ones. For children the defender from Gypsies are their parents.

Attitude towards Gypsies. The participants of the discussion expressed ambiguous attitude towards Gypsies: it is twofold due to the general agreement on the matter of existence of two different types of Gypsies, who are also different in their numbers. The first type is represented by Gypsies who are condemned by the society; they make up the majority and they are the "typical" representatives of this ethnic group. The second type is a small number of atypical Gypsies, who are, on the one hand, not condemned, on the other - they are difficult to identify as Gypsies. Generally though, Gypsies are referred to in the plural. They are either Gypsies' settlements, villages, encampmentss- including figurative meaning; or joint activities, carried out by a group of Gypsies. If the Gypsies are referred to in the singular, as a rule, atypical representatives of this ethnic group are meant.

The vast majority of the members of the discussion assessed Gypsies negatively or extremely negatively, such attitude to Gypsies being spread not only in Russia, but also abroad. People usually name two reasons for the negative attitude towards Gypsies. The first is the personal experience. Although the participant of the discussion said that not all Gypsies are bad, most of them have never met a good Gypsy. Secondly, the attitude of some of the participants towards Gypsies was formed in their childhood by the instructions of their parents. Individual participants of the discussion say that Gypsies scared them, they were perceives as fictional characters. The participants of the forum were divided in their opinions concerning the attitude towards Gypsies that their children should have. One group is tolerant and is not going to specifically tell their children about Gypsies. The other group is going to tell and is already telling the children negative things about Gypsies and is teaching them techniques to resist Gypsies.

Atypical Gypsies are rare, they are individual representatives of this ethnic group. The atypical can be manifested in several aspects. Firstly, absence of characteristic clothing is atypical. Secondly, absence of connection with criminal spheres and legal income. Thirdly, having education. Fourthly, settled way of life. Fifthly, respectful attitude to non-Gypsies, manifested in friendly or even family relations with representatives of other ethnic group.

The discussion also includes the opinion, according to which it is impossible to determine whether Gypsies are typical or atypical. As well as the extremely negative opinions that atypical Gypsies do not exist.

Attitude of Gypsies towards Gypsies and non-Gypsies. Judging by the analyzed discussion, Gypsies have a strong differentiation between their own group (Gypsies) and others (all the rest). It is interesting to consider the features, on which this 
differentiation is based. Being outwardly defined by their appearance, occupation, places of settlement, Gypsies seem to base the inside differentiation, principally, on blood and kinship belonging or not-belonging to this ethnic group. Such a conclusion is prompted by two things.

Firstly, describing Gypsies, the initiator of the discussion actively uses words, describing kinship affiliation- clan, tribe, family, brothers, sisters; other participants of the discussion adopt his method of classification. Secondly, participants of the discussion did not consider possessing "Gypsy blood" to be the reason for good attitude towards Gypsies. Such attitude to one's own roots is condemnable from the point of view of the Gypsy who initiated the discussion, because if a person admits to having Gypsy roots, he/she must adhere to the division between one's own kind and others and fully support Gypsies.

Having made the distinction between their own kind and others, Gypsies speak positively about the former. They (through the initiator of the debate) call themselves "people-festivities". A Gypsy vehemently defends Gypsy clans, that is, their own kind, even despite no participant attacked them. A Gypsy can steal from others, but not from a Gypsy. In this case, you can tell your own kind from the others by their appearance. The initiator of the discussion mentions only positive characteristics of Gypsies, for example, respect for old age. And he does it basing on the opposition of "us" and "them."

The attitude of Gypsies to "them-others" is rather bad, they do not respect them.

Ways of changing attitudes towards Gypsies. As a means to change attitude to Gypsies, the initiator of the discussion views films, books and other means of constructivism. Some participants of the discussion also believe that constructivism is a rather powerful tool, but Gypsies have used its results for their own gain.

The point of view of other participants of the discussion is that constructivism can be applied only on the basis of the really effective measures taken by Gypsies in order to improve their own behavior.

\section{DISCUSSION AND CONCLUSION}

Gypsies are identified by the representatives of other ethnic groups primarily by their appearance (mainly women and children), types of their occupation (negative and relatively positive) and places of settlement (villages, urban private sector), railway stations; there are practically no Gypsies in safe areas). Victims of illegal actions of Gypsies are, as a rule, women. The techniques to resist Gypsies are ignoring them, using their own methods, search for protection.

Gypsies clearly divide all people into their own kind and others, and they do so apparently on the basis of blood relations. They actively and even aggressively protect their own kind, justify them, they do not commit crimes against their own kind. Gypsies' attitude towards others is bad.

Attitude towards Gypsies is based on two components: firstly, personal experience (often negative), secondly, perceptions, formed by parents (also negative). Negative attitude extends to typical Gypsies, including all the previously listed characteristics; the participants of the discussion have a positive attitude towards atypical Gypsies.

Gypsies believe that the attitude of others to themselves can be changed solely by means of constructivism (in particular, with the help of works of art). 
Representatives of other ethnic groups believe that constructivism can be applied only on the basis of modified behaviour of Gypsies.

\section{REFERENCES}

[1] Rowe L. \& Goodman S. "A stinking filthy race of people inbred with criminality" A discourse analysis of prejudicial talk about Gypsies in discussion forums, Romani Studies, vol. 24/issue 1, pp 25-42, 2014.

[2] Jensen T. \& Ringrose J. Sluts that choose Vs doormat gypsies, Feminist Media Studies, vol. 14/issue 3, pp 369-387, 2014.

[3] Gypsy pogrom after the murder of a child in Odessa region. Topical, Medusa. Available at: https://meduza.io/feature/2016/08/30/tsyganskiy-pogrom-posle-ubiystvarebenka-v-odesskoy-oblasti-glavnoe

[4] The revolt of Gypsies in Tula region. Brief. Why was OMON brought to the village of Plekhanovo, Medusa. - Available at: https://meduza.io/feature/2016/03/17/bunttsygan-v-tulskoy-oblasti-korotko

[5] Surdu M. \& Kovats M. Roma identity as an expert-political construction, Social Inclusion, vol. 3/issue 5, pp 5-18, 2015.

[6] Fekete L. Europe against the Roma, Race and Class, vol. 55/issue 3, pp 60-70, 2014. [7] Koptseva N.P. \& Reznikova K.V. Refinement of the Causes of Ethnic Migration North Selkups Based on the Historical Memory of Indigenous Ethnic Groups Turukhansk District of Krasnoyarsk Krai, Bylye Gody, vol. 38/ issue 4, pp 1028-1038, 2015.

[8] Gay y Blasco, P. 'It's the best place for them': normalising Roma segregation in Madrid, Social Antropology, vol. 24/issue 4, pp 446-461, 2016.

[9] Acton T.A. Scientific racism, popular racism and the discourse of the Gypsy Lore Society, Ethnic and Racial Studies, vol. 39/issue 7, pp 1187-1204, 2016.

[10] Picker G. \& Greenfields M. \& Smith, D. Colonial refractions: the 'Gypsy camp' as a spatio-racial political technology, City, vol. 19/issue 5, pp 741-752, 2015.

[11] Ryder A. \& Cemlyn S. Monoculturalism, austerity and moral panics: Assessing government progress on addressing Gypsy, Traveller and Roma exclusion, Journal of Poverty and Social Justice, vol. 24/issue 2, pp 143-155, 2016.

[12] Surdu M. \& Kovats M. Roma identity as an expert-political construction, Social Inclusion, vol. 3/issue 5, pp 5-18, 2015.

[13] Tremlett A. Making a difference without creating a difference: Super-diversity as a new direction for research on Roma minorities, Ethnicities, vol. 14/issue 6, pp 830-848, 2014.

[14] Marushiakova E. \& Popov V. European policies for social inclusion of Roma: Catch 22?, Social Inclusion, vol. 3/issue 5, pp 19-31, 2015.

[15] Lashe tes, Russian sisters!, Live journal "Kids". - Available at: http://malyshi.livejournal.com/55739509.html?thread=1487011445\#t1487011445 